\title{
PREVALENCE AND RISK FACTORS FOR WHEEZING IN INFANTS IN THE REGION OF PAMPLONA, SPAIN
}

\author{
Ismael Alvarez-Alvarez ${ }^{1} \mathrm{Hao} \mathrm{Niu}^{1}$ Ines Aguinaga-Ontoso ${ }^{1}$ Francisco Guillen-Grima ${ }^{1,2,3}$ \\ ${ }^{1}$ Department of Health Sciences, Public University of Navarre, Pamplona, Spain \\ ${ }^{2}$ IDISNA, Navarra's Institute for Health Research, Pamplona, Spain. \\ ${ }^{3}$ Preventive Medicine, University of Navarra Clinic \\ Corresponding author:
}

Ismael Alvarez Alvarez

Department of Health Sciences. Public University of Navarre.

Avenida de Barañain, s/n 31008 Pamplona (Navarra) Spain

Public University of Navarre. (Spain)

E-mail: alvarez.80114@e.unavarra.es

This is an accepted manuscript published by Elsevier España in Allergologia et Immunopathologia on 11 August 2015.

This work should be cited as:

Alvarez-Alvarez I, Niu H, Aguinaga-Ontoso I, Guillen-Grima F. Prevalence and risk factors for wheezing in infants in the region of Pamplona, Spain. Allergol Immunopathol (Madr) 2016; 44(5): 415-21.

(C) 2015. This manuscript version is made available under the CC-BY-NC-ND 4.0 license http://creativecommons.org/licenses/by-nc-nd/4.0/ 


\begin{abstract}
Background: Wheezing in the first year of life affects life's quality of the baby and the family. Risk factors such as male gender, nursery attending or a family history of asthma, and protective factors such as breastfeeding more than 6 months have been previously described. The aim of this study is to study the prevalence and risk factors for wheezing ever and recurrent wheezing in the first year of life in infants in the region of Pamplona, Spain.

Material and methods: This cross-sectional study was part of the International Study of Wheezing in Infants (Estudio Internacional de Sibilancias en Lactantes, EISL). Between 2006 and 2008, participating families answered a standardized validated questionnaire on respiratory symptoms, environmental factors or family issues. An analysis with the chi square test (statistical significance $\mathrm{p}<0.05$ ) identified the risk factors for wheezing ever and recurrent wheezing, which were assessed using logistic regression.
\end{abstract}

Results: 1065 questionnaires were answered. The prevalence of wheezing ever and recurrent wheezing were $31.2 \%$ and $12.3 \%$, respectively. Male gender $(\mathrm{p}=<0.001)$, a history of pneumonia $(\mathrm{p}=<0.001)$ or nursery attendance $(\mathrm{p}=<0.001)$ were some of the risk factors found for wheezing ever. Infant eczema $(\mathrm{p}=<0.001)$, nursery attendance $(\mathrm{p}=<0.001)$ or prematurity $(\mathrm{p}=<0.001)$ were risk factors for recurrent wheezing. No associations with duration of breastfeeding ( $\mathrm{p}=0.116$ and $\mathrm{p}=0.851)$ or mould stains at home $(\mathrm{p}=0.153$ and $\mathrm{p}=0.992)$ were found.

Conclusion: The study of prevalence and risk factors for wheezing shows the importance of this public health problem, and allows the development of control and treatment strategies against preventable factors.

Keywords: asthma, epidemiology, infant, prevalence, risk factors, wheezing 


\section{INTRODUCTION}

Wheezing in infants is an important problem, affecting children's health-related quality of life (1), and can lead to asthma in childhood (2, 3).

Prevalence of wheezing ever in infants varies across different regions, from $29 \%$ in countries in Northern Europe, to $48 \%$ in countries in Southern Europe, and $27 \%$ in the United States of America (USA) (4). Previous studies have found associations between rainy weather and severe current wheeze in schoolchildren (5), and stronger associations of some risk and protective factors of recurrent wheezing when latitude increases (6).

Several risk factors have been described, being the most important male sex, familiar history of asthma, nursery attendance, history of pneumonia, smoking during pregnancy, mould stains in the house and breastfeeding less than 6 months (7-9). Protective factors as breastfeeding more than 8 months (10) and adherence to the Mediterranean diet (11) have been found.

Although previous studies about wheezing in infants have been conducted, none of them have studied the epidemiology of the disease in the North of Spain. The aim of this crosssectional study is to examine the prevalence and risk factors of wheezing ever and recurrent wheezing in the first year of life in infants from the region of Pamplona.

\section{MATERIALS AND METHODS}

\section{Study population}

This study was part of the International Study of Wheezing in Infants (in Spanish, Estudio Internacional de Sibilancias en Lactantes, EISL), an observational cross-sectional multicentre study conducted in countries of Europe and Latin America (12). 
In the region of Pamplona, this study was conducted between 2006 and 2008, where 20 primary care centres participated. The population of the study were the infants of the metropolitan area of Pamplona (an urban area consisting of Pamplona and adjacent cities) who went to a health revision at 15 months of age. The sample size was 3284 infants (from urban localities), all the children in the age range (12-15 months of age). Random sampling was not carried out, the questionnaire was given to all families, who were asked to complete it and return after completion. The study was approved by the Management of Primary Care of the Navarre's Health Service and the Scientific Ethic Committee of University of Murcia.

\section{Data collection}

Paediatric nurses of the primary health centres explained the study to the families, and if they agreed to participate, after signing a full-informed written consent, a questionnaire and the instructions to complete it were given. Families filled the questionnaire and could give it in the same primary health centre in the next visit, or send it to the Public University of Navarre by mail.

The questionnaire consisted of 74 questions about the infant (respiratory symptoms, feeding), his/her family (habits, diseases), environmental factors and pregnancy. No personal data were collected. This questionnaire has been previously validated (13). A Spanish version of the questionnaire was back translated to Basque (an official regional language) by the Department of Euskera of the Public University of Navarre, and both models were available.

Wheeze ever was defined as a positive answer to the question "Has your child wheeze in the first 12 months of his/her life?" Recurrent wheeze was defined as three or more episodes of wheezing in the first year of life. 


\section{Statistical analysis}

A descriptive analysis was carried out. Chi Square and student's-t test (as appropriate), with a statistical significance set at $\alpha<0.05$, were performed in a univariate analysis to study the associations between the presence of wheezing ever and recurrent wheezing and factors, and the odds ratios $(\mathrm{OR})$, with a confidence interval of $95 \%(95 \% \mathrm{CI})$ were calculated.

Non conditional logistic regression analysis to calculate adjusted odds ratios (aOR) by sex and age was used in those factors with $\mathrm{p}<0.1$. Analyses were performed with IBM SPSS version 20 (Armonk, NY, USA).

\section{RESULTS}

A total of 1065 questionnaires were answered, which meant a participation rate of 32.4\%. Results from the descriptive analysis are shown in Table 1. Prevalence of wheezing in the first year was $31.2 \%$ (327), and $12.3 \%$ (106) were recurrent wheezers. Most of the questionnaires were completed by the mothers $(79.9 \%)$ or both parents $(15.8 \%)$, and almost all the infants were white race and had born in Spain (96.8\% and 99.5\%, respectively). 121 (13.1\%) infants went to Emergency Department because of the severity of wheezing, and $27(2.7 \%)$ were hospitalized once and $3(0.3 \%)$ twice for this cause.

Risk factors for wheezing ever are shown in Table 2. A history of pneumonia, paternal allergic dermatitis and nursery attendance presented the largest OR. There were also associations between wheezing ever and a higher number of colds $(\mathrm{p}=<0.001$; aOR 1.164, 95\% CI 1.102-1.230) and number of persons at home ( $\mathrm{p}=0.037$; aOR 1.155, 95\% CI 1.008-1.323).

No associations were found with low weight at birth $(\mathrm{p}=0.268)$, pets, nor at birth or when the questionnaire was answered ( $p=0.810$ and $p=0.372$, respectively), mould stains in the house $(\mathrm{p}=0.153)$, or breastfeeding less than 6 months $(\mathrm{p}=0.116)$. 
Table 1. Results from the descriptive analysis

\begin{tabular}{|c|c|c|}
\hline Variables & $\mathrm{N}$ & $\%$ \\
\hline Study participation & 1065 & 32.4 \\
\hline Male gender & 519 & 50.3 \\
\hline Age (in months) & $12.08 \pm 0.94$ & \\
\hline Low weight at birth $(<2,500 \mathrm{~g})$ & 82 & 7.7 \\
\hline \multicolumn{3}{|l|}{ Wheezing } \\
\hline Ever & 327 & 31.2 \\
\hline Recurrent & 106 & 12.3 \\
\hline Age of first episode (in months) & $6.88 \pm 5.66$ & \\
\hline \multicolumn{3}{|l|}{ Colds } \\
\hline Number of colds & $3.78 \pm 3.60$ & \\
\hline Age of the first cold (in months) & $5.84 \pm 4.25$ & \\
\hline Pneumonia & 42 & 4.2 \\
\hline Eczema & 134 & 13.2 \\
\hline Smoking mother & 216 & 20.6 \\
\hline Smoking father & 306 & 29.8 \\
\hline Smoking in pregnancy & 170 & 16.2 \\
\hline \multicolumn{3}{|l|}{ Asthma } \\
\hline Father & 44 & 4.2 \\
\hline Mother & 53 & 5.3 \\
\hline Siblings & 28 & 2.8 \\
\hline \multicolumn{3}{|l|}{ Allergic rhinitis } \\
\hline Father & 135 & 13.1 \\
\hline Mother & 138 & 13.2 \\
\hline Siblings & 22 & 2.2 \\
\hline \multicolumn{3}{|l|}{ Allergic dermatitis } \\
\hline Father & 38 & 3.7 \\
\hline Mother & 61 & 5.9 \\
\hline Siblings & 55 & 5.9 \\
\hline \multicolumn{3}{|l|}{ Number of siblings } \\
\hline 0 & 542 & 50.9 \\
\hline 1 & 438 & 41.1 \\
\hline 2 & 64 & 6.0 \\
\hline 3 or more & 20 & 1.9 \\
\hline Number of persons at home & $3.45 \pm 0.99$ & \\
\hline Nursery attendance & 349 & 33.2 \\
\hline Breastfeeding (in months) & $5.50 \pm 4.99$ & \\
\hline \multicolumn{3}{|l|}{ Pets (at birth) } \\
\hline No pets & 853 & 81.9 \\
\hline Dog & 63 & 6.0 \\
\hline Cat & 33 & 3.2 \\
\hline \multicolumn{3}{|l|}{ Pets (when questionnaire was completed) } \\
\hline No pets & 840 & 81.0 \\
\hline Dog & 55 & 5.3 \\
\hline Cat & 33 & 3.2 \\
\hline Mould stains at home & 45 & 4.3 \\
\hline Atmospheric contamination & 263 & 25.1 \\
\hline
\end{tabular}


Table 2. Risk factors for wheezing ever in the first year of life

\begin{tabular}{|c|c|c|c|c|}
\hline Variables & $\mathrm{N}(\%)$ & p-value & $\begin{array}{c}\text { OR } \\
(95 \% \mathrm{CI})\end{array}$ & $\begin{array}{l}\text { Adjusted OR } \\
(95 \% \mathrm{CI})\end{array}$ \\
\hline Male gender & $193(60.7 \%)$ & $<0.001$ & $\begin{array}{c}1.825 \\
(1.393-2.390)\end{array}$ & $\begin{array}{c}1.836 \\
(1.398-2.413)\end{array}$ \\
\hline Pneumonia & $33(10.5 \%)$ & $<0.001$ & $\begin{array}{c}11.173 \\
(4.885-25.558)\end{array}$ & $\begin{array}{c}10.745 \\
(4.638-24.896)\end{array}$ \\
\hline Eczema & $57(18.0 \%)$ & 0.003 & $\begin{array}{c}1.764 \\
(1.215-2.561)\end{array}$ & $\begin{array}{c}1.886 \\
(1.278-2.783)\end{array}$ \\
\hline Smoking mother & $79(24.6 \%)$ & 0.027 & $\begin{array}{c}1.429 \\
(1.042-1.962)\end{array}$ & $\begin{array}{c}1.462 \\
(1.054-2.029)\end{array}$ \\
\hline Smoking father & $98(31.2 \%)$ & 0.444 & $\begin{array}{c}1.120 \\
(0.838-1.496)\end{array}$ & - \\
\hline Smoking in pregnancy & $65(20.1 \%)$ & 0.022 & $\begin{array}{c}1.491 \\
(1.058-2.102)\end{array}$ & $\begin{array}{c}1.617 \\
(1.133-2.308)\end{array}$ \\
\hline \multicolumn{5}{|l|}{ Asthma } \\
\hline Father & $20(6.2 \%)$ & 0.036 & $\begin{array}{c}1.900 \\
(1.034-3.492)\end{array}$ & $\begin{array}{c}1.926 \\
(1.027-3.611)\end{array}$ \\
\hline Mother & $25(8.0 \%)$ & 0.015 & $\begin{array}{c}1.978 \\
(1.133-3.452)\end{array}$ & $\begin{array}{c}1.749 \\
(0.978-3.126)\end{array}$ \\
\hline Siblings & $7(2.2 \%)$ & 0.428 & $\begin{array}{c}0.706 \\
(0.297-1.678)\end{array}$ & - \\
\hline \multicolumn{5}{|l|}{ Allergic rhinitis } \\
\hline Father & $38(12.0 \%)$ & 0.546 & $\begin{array}{c}0.883 \\
(0.590-1.322)\end{array}$ & - \\
\hline Mother & $53(16.5 \%)$ & 0.050 & $\begin{array}{c}1.447 \\
(0.998-2.099)\end{array}$ & $\begin{array}{c}1.391 \\
(0.946-2.045)\end{array}$ \\
\hline Siblings & $6(2.0 \%)$ & 0.674 & $\begin{array}{c}0.816 \\
(0.316-2.106)\end{array}$ & - \\
\hline \multicolumn{5}{|l|}{ Allergic dermatitis } \\
\hline Father & $19(6.0 \%)$ & 0.012 & $\begin{array}{c}2.258 \\
(1.178-4.326)\end{array}$ & $\begin{array}{c}2.492 \\
(1.268-4.896)\end{array}$ \\
\hline Mother & $19(5.9 \%)$ & 0.956 & $\begin{array}{c}0.984 \\
(0.563-1.721)\end{array}$ & - \\
\hline Siblings & $20(6.5 \%)$ & 0.454 & $\begin{array}{c}1.241 \\
(0.704-2.188)\end{array}$ & - \\
\hline Nursery attendance & $138(42.7 \%)$ & $<0.001$ & $\begin{array}{c}1.867 \\
(1.419-2.455)\end{array}$ & $\begin{array}{c}2.003 \\
(1.507-2.663)\end{array}$ \\
\hline Mould stains at home & $18(5.6 \%)$ & 0.153 & $\begin{array}{c}1.561 \\
(0.843-2.891)\end{array}$ & - \\
\hline Gestational diabetes & $29(9.6 \%)$ & 0.075 & $\begin{array}{c}1.572 \\
(0.952-2.596)\end{array}$ & $\begin{array}{c}1.501 \\
(0.882-2.553)\end{array}$ \\
\hline Prematurity & $32(11.0 \%)$ & 0.077 & $\begin{array}{c}1.526 \\
(0.953-2.442)\end{array}$ & $\begin{array}{c}1.461 \\
(0.892-2.393)\end{array}$ \\
\hline
\end{tabular}


In Table 3, risk factors for recurrent wheezing are presented. A history or pneumonia, infant eczema, nursery attendance and prematurity at birth were the most important risk factors. Higher number of colds $(\mathrm{p}=<0.001$; aOR 1.381, 95\% CI 1.266-1.505) and higher number of smokers at home $(\mathrm{p}=0.029$; aOR 1.328; 95\% CI 1.017-1,735) were also risk factors for recurrent wheezing. There were no associations with low weight at birth $(\mathrm{p}=0.158)$, mould stains $(\mathrm{p}=0.992)$, atmospheric contamination $(\mathrm{p}=0.708)$ or breastfeeding less than 6 months $(\mathrm{p}=0.851)$.

\section{DISCUSSION}

Wheezing in infants is a major problem, affecting not only the quality of life of infants, but also their families. Our study has found several risk factors related to wheezing ever and recurrent wheezing in infants from the region of Pamplona.

Prevalence of wheezing ever in infants in our study was $31.2 \%$, similar prevalence compared to others EISL studies conducted in Spain, in the city of Salamanca, which found $32.3 \%$ (14) and in Netherlands, $28.5 \%$ (7), but less prevalence than in Latin America countries, where mean prevalence was $47.3 \%$ (15). Prevalence of recurrent wheezing was $12.3 \%$, similar to the other Spanish EISL study (14), but lower than other European and Latin American studies $(7,9)$.

Male gender was a risk factor for wheezing ever and recurrent wheezing in our study. This finding is in accordance with which has been found in other studies $(16,17)$, suggesting a genetic role in the appearance of wheezing.

In our study, low birth weight did not show any association with wheezing ever or recurrent wheezing. Our results contrast with findings from another Brazilian study in which low birth was an independent risk factor for occasional wheezing (18). 
Table 3. Risk factors for recurrent wheezing in the first year of life

\begin{tabular}{|c|c|c|c|c|}
\hline Variables & $\mathrm{N}(\%)$ & p-value & $\begin{array}{c}\text { OR } \\
(95 \% \mathrm{CI})\end{array}$ & $\begin{array}{l}\text { Adjusted OR } \\
(95 \% \mathrm{CI})\end{array}$ \\
\hline Male gender & $64(61.0 \%)$ & 0.004 & $\begin{array}{c}1.852 \\
(1.208-2.842)\end{array}$ & $\begin{array}{c}1.838 \\
(1.198-2.821)\end{array}$ \\
\hline Pneumonia & $15(14.6 \%)$ & $<0.001$ & $\begin{array}{c}14.574 \\
(5.506-38.575)\end{array}$ & $\begin{array}{c}15.758 \\
(5.852-42.430)\end{array}$ \\
\hline Eczema & $25(24.0 \%)$ & $<0.001$ & $\begin{array}{c}2.941 \\
(1.723-5.019)\end{array}$ & $\begin{array}{c}3.134 \\
(1.811-5.425)\end{array}$ \\
\hline Smoking mother & $27(25.7 \%)$ & 0.028 & $\begin{array}{c}1.731 \\
(1.057-2.833)\end{array}$ & $\begin{array}{c}1.665 \\
(1.008-2.748)\end{array}$ \\
\hline Smoking father & $42(40.0 \%)$ & 0.022 & $\begin{array}{c}1.654 \\
(1.072-2.551)\end{array}$ & $\begin{array}{c}1.605 \\
(1.033-2.493)\end{array}$ \\
\hline Smoking in pregnancy & $25(24.0 \%)$ & 0.006 & $\begin{array}{c}2.033 \\
(1.217-3.396)\end{array}$ & $\begin{array}{c}2.034 \\
(1.208-3.426)\end{array}$ \\
\hline \multicolumn{5}{|l|}{ Asthma } \\
\hline Father & $7(6.7 \%)$ & 0.195 & $\begin{array}{c}1.780 \\
(0.737-4.302)\end{array}$ & - \\
\hline Mother & $11(10.9 \%)$ & 0.005 & $\begin{array}{c}2.858 \\
(1.332-6.131)\end{array}$ & $\begin{array}{c}2.806 \\
(1.290-6.102)\end{array}$ \\
\hline Siblings & $2(2.1 \%)$ & 0.662 & $\begin{array}{c}0.718 \\
(0.161-3.190)\end{array}$ & - \\
\hline \multicolumn{5}{|l|}{ Allergic rhinitis } \\
\hline Father & $14(13.6 \%)$ & 0.822 & $\begin{array}{c}1.073 \\
(0.578-1.992)\end{array}$ & - \\
\hline Mother & $24(22.9 \%)$ & 0.002 & $\begin{array}{c}2.275 \\
(1.343-3.852)\end{array}$ & $\begin{array}{c}2.234 \\
(1.298-3.845)\end{array}$ \\
\hline Siblings & $3(3.1 \%)$ & 0.566 & $\begin{array}{c}1.458 \\
(0.399-5.326)\end{array}$ & - \\
\hline \multicolumn{5}{|l|}{ Allergic dermatitis } \\
\hline Father & $6(5.9 \%)$ & 0.266 & $\begin{array}{c}1.699 \\
(0.661-4.364)\end{array}$ & - \\
\hline Mother & $6(5.8 \%)$ & 0.987 & $\begin{array}{c}1.008 \\
(0.409-2.480)\end{array}$ & - \\
\hline Siblings & $6(6.1 \%)$ & 0.539 & $\begin{array}{c}1.334 \\
(0.531-3.354)\end{array}$ & - \\
\hline Nursery attendance & $55(53.4 \%)$ & $<0.001$ & $\begin{array}{c}2.906 \\
(1.890-4.467)\end{array}$ & $\begin{array}{c}3.045 \\
(1.960-4.731)\end{array}$ \\
\hline Mould stains at home & $4(3.9 \%)$ & 0.992 & $\begin{array}{c}0.995 \\
(0.334-2.960)\end{array}$ & - \\
\hline $\begin{array}{l}\text { Malposition of the } \\
\text { foetus }\end{array}$ & $6(6.2 \%)$ & 0.036 & $\begin{array}{c}2.853 \\
(1.029-7.910)\end{array}$ & $\begin{array}{c}2.933 \\
(1.039-8.277)\end{array}$ \\
\hline Placental problems & $8(8.3 \%)$ & 0.055 & $\begin{array}{c}2.268 \\
(0.963-5.342)\end{array}$ & $\begin{array}{c}2.285 \\
(0.956-5.460)\end{array}$ \\
\hline Prematurity & $18(18.8 \%)$ & $<0.001$ & $\begin{array}{c}3.115 \\
(1.676-5.789) \\
\end{array}$ & $\begin{array}{c}3.112 \\
(1.653-5.856)\end{array}$ \\
\hline
\end{tabular}


A history of pneumonia and a higher number of colds were both risk factors for wheezing ever and recurrent wheezing. Several studies agree with these findings $(19,20)$, being pneumonia a strong risk factor for recurrent wheezing in European and Latin American countries (21). The relevance of infections of the respiratory tract has been previously studied, describing the relation between viral infections (22) and the development of wheezing.

In our study infant eczema presented a higher risk for both wheezing ever and recurrent wheezing. This relation was also found in another EISL study (14), although is not a general finding, suggesting it affects some populations. Garcia-Marcos et al. (21) found that infant eczema was a risk factor for pneumonia in infants, which suggest a role between eczema and the development of other risk factors which lead to wheezing.

We found that smoking mother, as well as smoking during pregnancy, were risk factors for wheezing ever and recurrent wheezing, findings which have been previously described in many studies (23-25). Although a Spanish study found that paternal smoking was not associated with wheezing (26), we found it as risk factor for recurrent wheezing. Our results also show that number of smokers at home was a risk factor for recurrent wheezing, according to the finding that household smoking increases the risk of wheeze (24). Exposure to smoke, especially during pregnancy, is related to decreased lung function in children (27), suggesting an important influence in the apparition of the disease.

As in our study, a parental history of asthma has been found as risk factors in many studies $(9,15)$. These results may suggest the existence of a hereditary mechanism for asthma and wheezing (28). Maternal allergic rhinitis was found as a risk factor for recurrent wheezing, and paternal allergic dermatitis for wheezing ever. These results agree with results from others EISL studies $(7,9)$, where allergic diseases were risk factors for wheezing ever and recurrent wheezing. 
Attending to nursery school was found as a risk factor for both wheezing ever and recurrent wheezing. Previous results are conflictive, with several studies which either not found any association (29), or described a protective effect (30), while others agree with our results (31). An explanation for our results may be that children who attended a nursery school were in contact with other children and different environment, increasing the exposure to possible risk factors.

We did not find any relation between mould stains in the house and wheezing ever or recurrent wheezing, contrary to the Dutch EISL study (7), which found damp housing as a strong risk factor in both cases. In our study, only a few families reported mould stains or damp at home, which may have affected our findings, causing an underestimation of its influence.

Complications during pregnancy, specifically prematurity and malposition of the foetus, were risk factors for recurrent wheezing. Both, prematurity (32) and malpresentation of the foetus (33) were previously found associated with recurrent wheezing and asthma. Premature infants are born with abnormalities in their airways, which probably provoke the apparition of wheezing (34). In the same way, malposition is supposed to affect the lung function of the foetus, which can cause respiratory problems at an early age.

Breastfeeding showed no association in our study. Findings from previous studies are conflictive. Breastfeeding was found as a protective factor in some of them (10). However, other studies did not reach any relationship (35), or even described breastfeeding as a risk factor for asthma in childhood (36). 
Although previous studies have described a protective effect in those children with pets in the house (37), probably due to the exposition at early age to certain microorganism that confer protection against asthma, findings are conflictive (38). Our results did not show any association between the presence of pets at home and wheezing ever or recurrent wheezing.

We did not find any relation with air pollution in our study. However, several studies have found associations between this factor and wheezing $(39,40)$. The questionnaire asked for a personal perception of air pollution level, which means a subjective measure that may have led to underestimation.

One of the strengths of this study was the use of a validated questionnaire, a wellrecognized tool which has been used in other studies. Moreover, this study is part of the multicentre EISL project, which enables the comparison of the results obtained with other centres from Spain or other countries. One of the limitations of the study is its cross-sectional design, although the main weakness is its low participation, probably due to the low participation of the immigrant population, and to data protection issues and authorizations of the Health System, which made not possible to send reminder letters or telephone calls to participants, which would have increased the participation, reducing the confusion of some results, or allows finding others.

In conclusion, wheezing in infants is a common disease, with several identified risk factors, like pneumonia, family history of asthma and nursery attendance. Further studies are needed to test if these findings are consistent, and intervention against the preventable factors should be addressed. 


\section{ACKNOWLEDGMENTS}

This study has been funded by two Research Grants from Carlos III Institute, Spanish Ministry of Health and Consumer Affairs Ref, PI 050918, and from the Department of Health, Government of Navarra, Spain, Ref 6106.

Conflict of interest: No author has any conflict of interest to declare. 


\section{REFERENCES}

1. Hafkamp-de Groen E, Mohangoo AD, Landgraf JM, de Jongste JC, Duijts L, Moll HA, et al. The impact of preschool wheezing patterns on health-related quality of life at age 4 years. Eur Respir J 2013; 41(4):952-59.

2. Jackson DJ, Gangnon RE, Evans MD, Roberg KA, Anderson EL, Pappas TE, et al. Wheezing rhinovirus illnesses in early life predict asthma development in high-risk children. Am J Respir Crit Care Med 2008; 178(7):667-72.

3. Kappelle L, Brand PLP. Severe episodic viral wheeze in preschool children: high risk of asthma at age 5-10 years. Eur J Pediatr 2012; 171(6):947-54.

4. Bisgaard H, Szefler S. Prevalence of asthma-like symptoms in young children. Pediatr Pulmonol 2007; 42(8):723-28.

5. Arnedo-Pena A, Garcia-Marcos L, Bercedo-Sanz A, Aguinaga-Ontoso I, Gonzalez-Diaz C, Garcia-Merino A, et al. Prevalence of asthma symptoms in schoolchildren, and climate in west European countries: an ecologic study. Int J Biometeorol 2013; 57(5):775-84.

6. Garcia-Marcos L, Mallol J, Sole D, Brand PLP, Sanchez-Bahillo M, Sanchez-Solis M, et al. Latitude modifies the effect size of factors related to recurrent wheeze in the first year of life. Respir Med 2013; 107(5):665-72.

7. Visser CAN, Garcia-Marcos L, Eggink J, Brand PLP. Prevalence and risk factors of wheeze in Dutch infants in their first year of life. Pediatr Pulmonol 2010; 45(2):149-56.

8. Bianca AD, Wandalsen G, Mallol J, Sole D. Risk factors for wheezing disorders in infants in the first year of life living in São Paulo, Brazil. J Trop Pediatr 2012; 58(6):501-04.

9. Costa Bessa OAA, Madeiro Leite AJ, Sole D, Mallol J. Prevalence and risk factors associated with wheezing in the first year of life. Jornal de Pediatria 2014; 90(2):190-96. 
10. Oddy WH, Sly PD, de Klerk NH, Landau LI, Kendall GE, Holt PG, et al. Breast feeding and respiratory morbidity in infancy: a birth cohort study. Arch Dis Child 2003; 88(3):22428

11. Castro-Rodriguez JA, Garcia-Marcos L, Alfonseda JD, Valverde-Molina J, Sanchez-Solis M. Mediterranean diet as a protective factor for wheezing in preschool children. J Pediatr 2008; 152(6):823-28.

12. Observatorio del Estudio Internacional de Sibilancias en Lactantes (EISL) [Internet] 2015 April 10 Available from: http://www.respirar.org/respirar/epidemiologia/observatorio-del$\underline{\text { estudio-internacional-de-sibilancias-en-lactantes-eisl }}$

13. Mallol J, Garcia-Marcos L, Aguirre V, Martinez-Torres A, Perez-Fernández V, Gallardo A, et al. The International Study of Wheezing in Infants: Questionnaire Validation. Int Arch Allergy Immunol 2007; 144(1):44-50.

14. Pellegrini-Belinchon J, Miguel-Miguel G, De Dios-Martín B, Vicente-Galindo E, LorenteToledano F, Garcia-Marcos L. Study of wheezing and its risk factors in the first year of life in the Province of Salamanca, Spain. The EISL Study. Allergol Immunopathol 2012; 40(3):164-71.

15. Mallol J, Garcia-Marcos L, Sole D, Brand P, the EISL Study Group. International prevalence of recurrent wheezing during the first year of life: variability, treatment patterns and use of health resources. Thorax 2010; 65(11):1004-09.

16. Garcia-Marcos L, Mallol J, Sole D, Brand PLP, the EISL Study Group. International study of wheezing in infants: risk factors in affluent and non-affluent countries during the first year of life. Pediatr Allergy Immunol 2010; 21(5):878-88.

17. Caudri D, Savenije OEM, Smit HA, Postma DS, Koppelman GH, Wijga AH, et al. Perinatal risk factors for wheezing phenotypes in the first 8 years of life. Clin Exp Allergy 2013; 43(12):1395-1405. 
18. Reis GG, Miranda VM, Cardoso M-RA, Sole D, Barral A, Nascimento-Carvalho CM. Prevalence and risk factors for wheezing in Salvador, Brazil: a population-based study. The Quarterly Journal of Medicine 2015; 108(3):213-18.

19. Medeiros D, Silva AR, Rizzo JA, Sarinho E, Mallol J, Sole D. Prevalence of wheezing and associated risk factors among infants in Recife, Pernambuco State, Brazil. Cadernos de Saude Publica 2011; 27(8):1551-59.

20. Moraes LSL, Takano OA, Mallol J, Sole D. Risk factors associated with wheezing in infants. Jornal de Pediatria 2013; 89(6):559-66.

21. Garcia-Marcos L, Mallol J, Sole D, Brand PLP, Martinez-Torres A, Sanchez-Solis M, et al. Pneumonia and wheezing in the first year: an international perspective. Pediatr Pulmonol 2015 (In press).

22. Takeyama A, Hashimoto K, Sato M, Sato T, Tomita Y, Maeda R, et al. Clinical and epidemiological factors related to subsequent wheezing after virus-induced lower respiratory tract infections in hospitalized pediatric patients younger than 3 years. Eur $\mathbf{J}$ Pediatr 2014; 173(7):959-66.

23. Duijts L, Jaddoe VWV, van der Valk RJP, Henderson JA, Hofman A, Raat H, et al. Fetal exposure to maternal and paternal smoking and the risk of wheezing in preschool children: The Generation R Study. Chest 2012; 141(4):876-85.

24. Burke H, Leonardi-Bee J, Hashim A, Pine-Abata H, Chen Y, Cook DG, et al. Prenatal and passive smoke exposure and incidence of asthma and wheeze: systematic review and metaanalysis. Pediatrics 2012; 129(4):735-44.

25. Schvartsman C, Lima Farhat SC, Schvartsman S, Nascimento Saldiva PH. Parental smoking patterns and their association with wheezing in children. Clinics 2013; 68(7):93439. 
26. Jurado D, Muñoz C, de Dios Luna J, Muñoz-Hoyos A. Is maternal smoking more determinant than paternal smoking on the respiratory symptoms of young children? Respir Med 2005; 99(9):1138-44.

27. Gilliland FD, Berhane K, McConnell R, Gauderman WJ, Vora H, Rappaport EB, et al. Maternal smoking during pregnancy, environmental tobacco smoke exposure and childhood lung function. Thorax 2000; 55(4):271-76.

28. Paaso EMS, Jaakkola MS, Rantala AK, Hugg TT, Jaakkola JJK. Allergic diseases and asthma in the family predict the persistence and onset-age of asthma: a prospective cohort study. Respiratory Research 2014; 15:152.

29. Celedon JC, Litonjua AA, Ryan L, Weiss ST, Gold DR. Day care attendance, respiratory tract illnesses, wheezing, asthma, and total serum IgE level in early childhood. Arch Pediatr Adolesc Med 2002; 156(3):241-45.

30. Nicolaou NC, Simpson A, Lowe LA, Murray CS, Woodcock A, Custovic A. Day-care attendance, position in sibship, and early childhood wheezing: A population-based cohort study. J Allergy Clin Immunol 2008; 122(3):500-06.

31. Hagerhed-Engman L, Bornehag C-G, Sundell J, Aberg N. Day-care attendance and increased risk for respiratory and allergic symptoms in preschool age. Allergy 2006; 61(4):447-53.

32. Kumar R, Yu Y, Story RE, Pongracic JA, Gupta R, Pearson C, et al. Prematurity, chorioamnionitis, and the development of recurrent wheezing: a prospective birth cohort study. J Allergy Clin Immunol 2008; 121(4):878-84.

33. Annesi-Maesano I, Moreau D, Strachan D. In utero and perinatal complications preceding asthma. Allergy 2001; 56(6):491-97. 
34. Broughton S, Thomas MR, Marston L, Calvert SA, Marlow N, Peacock JL, et al. Very prematurely born infants wheezing at follow-up: lung function and risk factors. Arch Dis Child 2007; 92(9):776-80.

35. Miyake Y, Tanaka K, Sasaki S, Kiyohara C, Ohya Y, Fukushima W, et al. Breastfeeding and the risk of wheeze and asthma in Japanese infants: the Osaka Maternal and Child Health Study. Pediatr Allergy Immunol 2008; 19(6):490-96.

36. Sears MR, Greene JM, Willian AR, Taylor DR, Flannery EM, Cowan JO, et al. Long-term relation between breastfeeding and development of atopy and asthma in children and young adults: a longitudinal study. Lancet 2002; 360(9337):901-07.

37. Litonjua AA, Milton DK, Celedon JC, Ryan L, Weiss ST, Gold DR. A longitudinal analysis of wheezing in young children: The independent effects of early life exposure to house dust endotoxin, allergens, and pets. J Allergy Clin Immunol 2002; 110(5):736-42.

38. Apelberg BJ, Aoki Y, Jaakkola JJK. Systematic review: Exposure to pets and risk of asthma and asthma-like symptoms. J Allergy Clin Immunol 2001; 107(3):455-60.

39. Ryan PH, LeMasters G, Biagini J, Bernstein D, Grinshpun SA, Shukla R, et al. Is it traffic type, volume, or distance? Wheezing in infants living near truck and bus traffic. J Allergy Clin Immunol 2005; 116(2):279-84.

40. Andersen ZJ, Loft S, Ketzel M, Stage M, Scheike T, Hermansen MN, et al. Ambient air pollution triggers wheezing symptoms in infants. Thorax 2008; 63(8):710-16. 